\title{
Analysis of the determinants of trade balance: Case study of Tanzania
}

\author{
Moses Joseph Shawa*, Yao Shen \\ School of Economics, Shanghai University, Shanghai, China \\ Email address: \\ shamoses2002@yahoo.com(M. J. Shawa)
}

\section{To cite this article:}

Moses Joseph Shawa, Yao Shen. Analysis of the Determinants of Trade Balance: Case Study of Tanzania. International Journal of Business and Economics Researc. Vol. 2, No. 6, 2013, pp. 134-141. doi: 10.11648/j.ijber.20130206.13

\begin{abstract}
The study focuses on the Analysis of the Main determinants that have an impact on trade balance. Specifically this study focus on the main cause of Trade deficit in Tanzania by analyzing the impact of Foreign Direct Investment(FDI),Human Capital Development(HCD),Household Consumption Expenditure(HCEXP), Government Expenditure (GEXP),Inflation (INF),Natural Resources Availability (NRA), Real Exchange Rate (REX) and Foreign Income(WY) and Trade Liberization (TLB) etc.In this study The Ordinary Least Square method (OLS) under the E-View 7.1 software has been used for the econometric analysis with a sample period spanning from 1980-2012. The literature reviews of the previous researchers have the mixed results on the factors in questions. However this study tried to use more variables that have rarely been explored specifically in Tanzania and found out that the main influencing factors for the case of Tanzania are Foreign Direct Investment(FDI),Human Capital Development (HCD),Household Consumption Expenditure(HCEXP), Government Expenditure (GEXP),Inflation (INF),Natural Resources Availability (NRA),Foreign Income(WY) and Trade Liberization(TLB) so suggested policy measures should focus on them to reduce the trade deficit in the Tanzanian economy.
\end{abstract}

Keywords: Trade Balance(TB), Foreign Direct Investment(FDI), Human Capital Development(HCD), Natural Resources Availability (NRA), Foreign Income(WY), Trade Liberization(TLB), Tanzania

\section{Introduction}

The Trade balance of most of the Sub-Saharan African countries over many years has not been so encouraging. In fact a lot of these countries have been experiencing trade deficits in their economy. One of the main reasons for such performance is the poor economic strategies that have been adopted by these countries in their economic reforms and also most of these countries usually depends on certain specific primary products for their exports and import a lot of the manufactured goods hence huge trade deficit in their economy.

Tanzania is not an exception of this group of countries that have implemented several economic policies with the purpose of improving trade balance and promote its economic development. Since early 1970's and 1980s the values of Tanzania Imports have greatly exceeded exports, resulting in large trade deficits in the economy.

Some major policies like trade Liberalization was introduced and effectively implemented in 1993 with the purpose to improve the trade balance without any significant

improvement until very recently.

That scenario can be well observed from figure 1 below which shows that the trade balance continued to remain unfavorable (deficit) until very recently (but due to space problem only few recent years data have been shown in this figure 1). Therefore the unfavorable trade balance that exists in many African countries leads many researchers to continue exploring the factors that influence trade balance using different variables, models and period of studies.

\subsection{Tanzania Import, Export and Trade Balance with the Rest of the World}

In 2011 Tanzania recorded a trade balance deficit amounted USD -4,532.6 million compared to that recorded in 2010 which amounted to USD -2,647.9 million (figure 1). The expansion of the deficit was mainly caused by the increase in the value of goods imports, compared to the value of exports. 


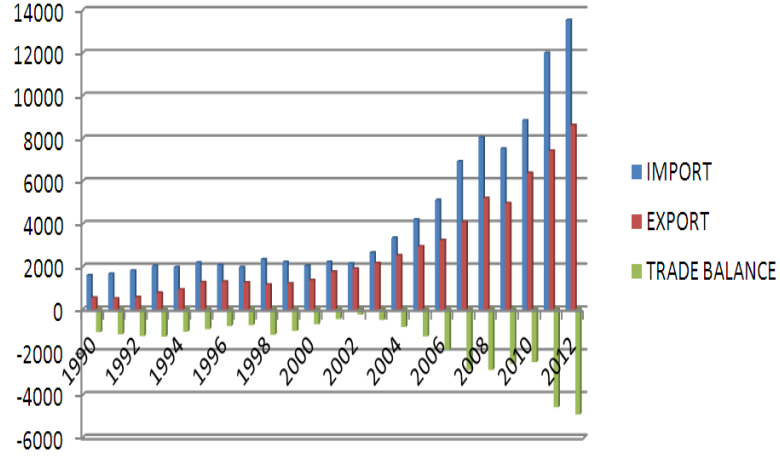

Source: world development indicators (2012).

Figure 1. The Tanzania's import, Export and trade balance 1990-2012 to the rest of the world (in mil.usd).

\subsection{Statement of the Problem}

Many developing countries especially Sub-Saharan African Countries have been experiencing Trade deficits for decades. Tanzania specifically presents a very good example as one of these countries in which it has been experiencing trade deficit before and after implementation of the structure adjustment programs like trade liberization.

Due to this prolonged trade imbalance then it makes sense to continue re-examining some factors that could be the main cause of this trade deficit and identify them.

\subsection{Objective of the Study}

The main objective of this study is to re-examine by estimating and identifying the main factors that affect Tanzania's trade balance while the specific objectives of the study is to find out the main cause of the trade deficit so that new policy measures can be raised up to reduce the range of trade deficit which lies in Tanzania trade balance.

\subsection{Significance of the Study}

The significance of this research is to provide a better knowledge and understanding of the factors that affect trade balance and also identify in which point Tanzania is not doing better so that more effort and new measures can be taken to increase economic growth which will come by exporting more and importing less and hence reduce the range trade deficit of this country and if possible attain trade surplus.

\subsection{Scope and Limitation of the Study}

The research limits itself to the trade balance in both goods and services in Tanzania. Basing on the period of study of about thirty three years (1980-2012). The choice of this period has been done according to the availability of the data for most of the variables that will be used in the research.

It should be noted that most of the literature review from the previous researchers that conducted the similar study analyzed mostly the variables like the real exchange rate, domestic income, foreign income, foreign direct investment and money supply but this study try to cover that gap by exploring other variables that only few literature review were available and the fact that they might have an impact for the Tanzanian economy for example in this study the human capital development, natural resources availability has been included into the analysis that most other researchers did not include in their analysis on the same subject especially in Tanzania when analyzing trade balance hence we expect to add contribution to the existing literature. The inclusion of these two variables from the theoretical point of view seems to be very important especially in the developing countries in Africa where we see natural resources endowments and education plays a very big role.

\section{The Review of Relevant Literature}

Studies on the issues relating to the determinants of trade balance have been conducted by previous researchers with mixed results for example the following.

[16] examined the determinant of trade balance in Tanzania by focusing on trade in goods from the year 1970's until 2002 using the variables like real exchange rate, foreign income, FDI, household consumption, Government expenditure and Trade liberization. In his study he used the ordinary least square (OLS) method for the estimations of the variables and found out that only three variables namely Government expenditure, household consumption and trade liberization were the main determinant of balance of trade in Tanzania. His study will differ with this study by employing three more variables like the human capital development, availability of natural resources, inflation and the period covered for the study.

[4] investigated the determinants of trade balance by using OLS for the period between 1970 to 2010.In his studies he used variables like real exchange rate, governments consumption expenditure, foreign income, domestic income, foreign direct investment and money supply(M3) and discovered that real exchange rate, governments consumption expenditure, domestic income, and money supply(M3) were the main significant factor in Kenya while the results found foreign income not to be significant factor.

[5] in his study of the effects of budget deficit on trade balance in Nigeria found some evidence from policy simulations and shows that budget deficit arising from increased government spending adversely affects the trade balance irrespective of whether it is money-financed or by external borrowing.

[13] did studies on the trade balance effects of U.S. foreign direct investment in Mexico. His analysis shows that the rise of intrafirm exports and imports following U.S.FDI in Mexico suggests that FDI affects trade flows.

[15] contrary to other authors argues that "response of the trade balance to the real exchange rate varies by country with the nature of the trade." They then investigated the short-run and long-run response of the bilateral trade 
balance to a change in real bilateral exchange rate between the United States and each of its major trading partners (Canada, France, Germany, Italy, and Japan) and concluded that there is no statistically significant relationship between trade balance and real exchange rate, either in the short run or in the long run.

[12] was the first to notice that the U.S. trade balance deteriorated despite devaluation of the dollar in 1971. He then theoretically argued that it is possible for the trade balance to deteriorate subsequent to currency depreciation, mostly due to lags in the response of trade flows to a change in exchange rate but once the lags are realized then eventually the trade balance improves.

[7] investigated real exchange rate and trade balance relationship in Malaysia for a period between 1955 to 2006,their empirical study showed that there is an existence of long run relationship between trade balance and exchange rate ,other major variables that were significant includes the domestic income and foreign income. Their results also indicated the no j-curve effect in Malaysia.

[9] analyzed the determinants of the Turkish trade balance using the ARDL bounds testing, his estimation results indicated that real exchange rate depreciations improves the trade balance with a strong and significant value while domestic real income affects the trade balance negatively and that trade balance is strongly improved due to an increase in foreign real income. No significant effect of crude oil prices can be observed on trade balance.

[11] analyzed a dynamic panel data analysis on the determinants of trade balance of Bangladesh for about 26 years with variables like real GDP, relative GNI, real exchange rate and import weighted index and discovered that import weighted index is significant in both short run and long run while other remaining variables were significant only in short run.

[17] examined the determinants of Pakistan's trade balance using ARDL Co integration approach for a period between 1970 to 2005 and found the existence of a stable relationship between trade balance and income, money supply and exchange rates. The exchange rate results confirmed the marshal learner condition with a depreciation which was positively related to trade balance.

[8] investigated the determinants of trade balance and adjustment to the crisis in Indonesia. His results suggested that trade balance will improve due to the devaluation through an increase in exports and a collapse in imports. Since the elasticity of import with respect to real exchange rate was higher than that of export then according to him that phenomenon implied that trade balance improvement would come from the import compression.

\section{The Methodology of the Study and Data Source}

\subsection{Theoretical Framework of the Model}

Trade balance is usually measured as the difference between the values of total exports and total imports. This study like the previous measures trade balance as the ratio of the exports value (EX) to the imports value (IM) $[1,2,10]$ also applying the logarithmic form on both sides (natural logarithm) of the equation [15]. The reduced form of the equation is given as follows:

Defn; $T B=E X-I M$

$T B=f(F D I, H C D, H C E X P, G E X P, I N F, N R A, R E X, W Y$,

$T L B, \varepsilon)$

$L N B T=L N(E X) / L N(I M)$

$L N T B=L N f(F D I, H C D, H C E X P, G E X P, I N F, N R A, R E X$, $W Y, T L B, \varepsilon)$

$L N T B=C+\beta_{1} L N F D I+\beta_{2} L N H C D+\beta_{3} L N H C E X P+\beta_{4} L n G E X P$ $+\beta_{5} L N I N F+\beta_{6} L N N R A+\beta_{7} L N R E X+\beta_{9} L N W Y+\beta_{10} T L B+\varepsilon$

Where;

TB refers to Trade balance which has been specified as a function of.

Respectively Foreign Direct Investment(FDI),Human Capital Development(HCD),Household Consumption Expenditure(HCEXP), Government

Expenditure(GEXP),Inflation(INF),Natural Resources Availability (NRA), Real Exchange Rate(REX),Foreign Encome(WY) and Trade Liberization(TLB).

The study used the same approach used by previous researchers who investigated the determinant of trade balance. However some modification has been made to suit the Tanzanian situation.

\subsection{Hypothesis of the Study}

This study is testing the hypothesis of zero influence of independent variables to dependent variable. It attempt to find out whether the independent variables have significant influence on dependent variable or not, that is $\pi$ is significantly equal to zero or not. Mathematically this hypothesis can be written as:

$$
\begin{aligned}
& \mathrm{H}_{0}: \pi=0 \\
& \mathrm{H}_{1}: \pi \neq 0
\end{aligned}
$$

\subsection{Brief Explanation of Variable}

Real Exchange Rate (REX):

REX the rise of domestic price (Devaluation/depreciation) means import (IM) will becomes more expensive than Export (EX) so with devaluation we expect to have a positive sign: [1] noted that in an effort to gain international competitiveness and help to improve its trade balance, a country may let its currency to devaluate or allow her currency to depreciate.

On the contrary the decrease of real exchange rate (evaluation/appreciation) may lead to the deterioration of 
balance of trade in this case the negative sign is expected. Household Consumption Expenditure (LNHCEXP):

The rise of Household consumption expenditure especially on import which might be due to the rise of income tends to worsen trade balance. Hence we expect that to have a negative sign.

Foreign Income (WY):

As the foreign income increase then more is expected to be imported from Tanzania hence this will improve the trade balance of the country. Therefore it is expected to have a positive sign. For the purpose of this study the Real GDP of the major importing country is used as a proxy for foreign income and for simplicity reason, USA is selected to represent the income from the rest of the world (foreign income) in order to make it easy to identify the main variables that have an influence for the context Tanzania mainland as a whole. The reason for selecting USA is the close bilateral trade relationship that existed between the USA market and Tanzania for a long time and this is due the fact that USA is the destination for Tanzania primary products (imports) and Tanzania is also the main destination for USA manufactured goods. Moreover the Tanzania is one of the developed country that is benefited on the African Growth and Opportunity Act (AGOA) initiative that has been established by the USA for the purpose of increasing trade between sub Saharan African countries and USA.Under this iniative the Sub African countries have some trade preferences that enable them to export to USA on duty-free which gives them more opportunities for their exports.

Government Expenditure (GEXP):

The rise of this will worsen trade balance and so it is expected to have a negative sign. Since increase in expenditure in non productive sectors always tends to have a negative effect on the trade balance of the country.

Foreign Direct Investment (FDI):

Foreign direct investment assist in improving trade balance especially if the multinational company motives is for export in this case we expect the positive sign however as noted by other researchers that it is possible FDI to have a negative impact on trade balance as it may be accompanied by the higher importation of the intermediate goods and the fact that FDI take sometimes to be realized however in this study we hypothesize a positive sign.

Human Capital Development (HCD):

The higher the human capital development the higher will be the economic growth of the country hence improvement on the trade balance can easily be realized and vice versa. In this study, human capital development implies the level of education attained in the ability to perform labor so as to produce economic value for the Tanzanian people who in turn are the major employees in the various economic and productive sectors in Tanzania. The study hypothesizes the human capital development to have a positive sign and is therefore measured by the number of enrollment of secondary education in Tanzania.

Inflation (INF)

When inflation is low, it implies that the economy is in the "loose money cycle" and when inflation is high, it means that the economy is in "tight money cycle". In theory, when the economy is in the "loose money cycles" usually there is a higher trade deficit due to the monetary policy of allowing more credit with lower interest rates. As the rates increase, the money will get tighter and fewer will be willing to lend the money as ownership becomes more attractive. This will trickle into the creating lower costs of production (labor, environment, and other production factors) there-by leading to the improvement of trade balance positively.

Natural Resources Availability (NRA)

The higher the availability of natural resources tends to impacts the trade balances positively

Trade Liberization (TLB)

Impacts positively on trade balance due to removal of trade restriction in Tanzania to the outside world. In this study we take trade liberization as a dummy variable to capture its impact on trade balance before and after it was effectively implemented in 1993 due to higher trade deficit. Therefore we hypothesize it to take a value of " 1 " after the period of trade liberization and takes value " 0 " otherwise.

\subsection{The Source and Data Type}

The study used the annual (secondary) time series data covering the period between1980-2012. This period has been chosen because data to be used in the trade balance function was likely to be available.

Equation is estimated using ordinary least square technique with selected data on Tanzania .Unless otherwise specified, all the data has been drawn from the International Financial Statistics Year Book, the Central Bank of Tanzania (BOT), world development indicators (WDI), publications and websites.

\section{The Data Analysis, Empirical Results and Interpretation}

\subsection{ADF and Phillips- Perron Test}

First of all we run the augmented Dickey-Fuller (ADF) and Phillip-Peron (PP) unit root tests for each variable that enters the multivariate model following the methodology implemented by [3,5] and [14]testing for the significance of the independent variables and assuming that the choice of lags is based to guarantee non-residual autocorrelation. The results over the period after first difference only are reported in Table 1.The over all test shows that all variables contain a unit root at levels while they were all found to be stationary after the first difference. 
Table 1. Stationary (unit root) test for variables

\begin{tabular}{|c|c|c|c|c|c|}
\hline Variables & $\begin{array}{l}\text { ADF } \\
\text { Statistics }\end{array}$ & Critical Values & $\begin{array}{l}\text { Phillips-Perron } \\
\text { Statistics }\end{array}$ & Critical Values & Decision \\
\hline LN TB & $\begin{array}{l}4.845447 * \\
(0.0005)\end{array}$ & $\begin{array}{l}1 \%=-3.661661 \\
5 \%=-2.960411 \\
10 \%=-2.619160\end{array}$ & $\begin{array}{l}-4.798520 * \\
(0.0005)\end{array}$ & $\begin{array}{l}1 \%=-3.661661 \\
5 \%=-2.960411 \\
10 \%=-2.619160\end{array}$ & $\begin{array}{l}\text { Stationery at } 1 \mathrm{st} \\
\text { difference }\end{array}$ \\
\hline LNFDI & $\begin{array}{l}-8.200455 * \\
(0.0000)\end{array}$ & $\begin{array}{l}1 \%=-3.670170 \\
5 \%=-2.963972 \\
10 \%=-2.621007\end{array}$ & $\begin{array}{l}-10.95014 * \\
(0.0000)\end{array}$ & $\begin{array}{l}1 \%=-3.661661 \\
5 \%=-2.960411 \\
10 \%=-2.619160\end{array}$ & $\begin{array}{l}\text { Stationery at } 1 \mathrm{st} \\
\text { difference }\end{array}$ \\
\hline LNHCD & $\begin{array}{l}4.112854 \\
(1.0000)\end{array}$ & $\begin{array}{l}1 \%=-3.737853 \\
5 \%=-2.991878 \\
10 \%=-2.635542\end{array}$ & $\begin{array}{l}-6.392028 \\
(0.0000)\end{array}$ & $\begin{array}{l}1 \%-3.661661 \\
5 \%-2.960411 \\
10 \%-2.619160\end{array}$ & $\begin{array}{l}\text { Stationery at } 1 \mathrm{st} \\
\text { difference }\end{array}$ \\
\hline LNHCEXP & $\begin{array}{l}-3.432900 * * \\
(0.0173)\end{array}$ & $\begin{array}{l}1 \%=-3.661661 \\
5 \%=-2.960411 \\
10 \%=-2.619160\end{array}$ & $\begin{array}{l}-3.432900 * * \\
(0.0173)\end{array}$ & $\begin{array}{l}1 \%=-3.661661 \\
5 \%=-2.960411 \\
10 \%=-2.619160\end{array}$ & $\begin{array}{l}\text { Stationery at } 1 \mathrm{st} \\
\text { difference }\end{array}$ \\
\hline LNGEXP & $\begin{array}{l}-4.528744 \\
(0.0011)\end{array}$ & $\begin{array}{l}1 \%=-3.661661 \\
5 \%=-2.960411 \\
10 \%=-2.619160\end{array}$ & $\begin{array}{l}-4.572816 \\
(0.0010)\end{array}$ & $\begin{array}{l}1 \%=-3.661661 \\
5 \%=-2.960411 \\
10 \%=-2.619160\end{array}$ & $\begin{array}{l}\text { Stationery at } 1 \mathrm{st} \\
\text { difference }\end{array}$ \\
\hline LNINF & $\begin{array}{l}-7.781200 \\
(0.0000)\end{array}$ & $\begin{array}{l}1 \%=-3.661661 \\
5 \%=-2.960411 \\
10 \%=-2.619160\end{array}$ & $\begin{array}{l}-8.248781 \\
(0.0000)\end{array}$ & $\begin{array}{l}1 \%=-3.661661 \\
5 \%=-2.960411 \\
10 \%=-2.619160\end{array}$ & $\begin{array}{l}\text { Stationery at } 1 \mathrm{st} \\
\text { difference }\end{array}$ \\
\hline LNNRA & $\begin{array}{l}-4.510062 \\
(0.0012)\end{array}$ & $\begin{array}{l}1 \%=-3.661661 \\
5 \%=-2.960411 \\
10 \%=-2.619160\end{array}$ & $\begin{array}{l}-4.471967 \\
(0.0013)\end{array}$ & $\begin{array}{l}1 \%=-3.661661 \\
5 \%=-2.960411 \\
10 \%=-2.619160\end{array}$ & $\begin{array}{l}\text { Stationery at } 1 \mathrm{st} \\
\text { difference }\end{array}$ \\
\hline LN REX & $\begin{array}{l}-3.902650 * \\
(0.0057)\end{array}$ & $\begin{array}{l}1 \%=-3.670170 \\
5 \%=-2.963972 \\
10 \%=-2.621007\end{array}$ & $\begin{array}{l}-3.819134 * \\
(0.0068\end{array}$ & $\begin{array}{l}1 \%=-3.661661 \\
5 \%=-2.960411 \\
10 \%=-2.619160\end{array}$ & $\begin{array}{l}\text { Stationery at } 1 \text { st } \\
\text { difference }\end{array}$ \\
\hline LNWY & $\begin{array}{l}-3.066817 * \\
(0.0397)\end{array}$ & $\begin{array}{l}1 \%=-3.661661 \\
5 \%=-2.960411 \\
10 \%=-2.619160\end{array}$ & $\begin{array}{l}-2.795483^{*} \\
(0.0705)\end{array}$ & $\begin{array}{l}1 \%=-3.661661 \\
5 \%=-2.960411 \\
10 \%=-2.619160\end{array}$ & $\begin{array}{l}\text { Stationery at } 1 \mathrm{st} \\
\text { difference }\end{array}$ \\
\hline
\end{tabular}

Source: Computation from data used in Regression Analysis.

The table above shows unit root tests. The notations:

(LNTB),(LNFDI),(LNHCD),(LNHCEXP),(LNGEXP),( LNINF),(LNNRA),(LNREX),(LNWY), indicate respectively the Balance of trade, Foreign direct investment, Human capital development, Household consumption expenditure, Government expenditure,Inflation,Natural resources availability, Real exchange rate and foreign income.
The asterisks $*, * *$, and $* * *$ denote statistical significance at $1 \%, 5 \%$, and $10 \%$ levels, respectively. McKinnon (1980) critical values are used for rejection of the null unit root.

\subsection{Ordinary Least Squares (OLS)}

Secondly we performed the ordinary least squares (OLS) and the results were presented as follows below:

Table 2. Ordinary least squares (OLS) results

\begin{tabular}{|c|c|c|c|c|}
\hline \multicolumn{5}{|c|}{ Dependent Variable:LNBT } \\
\hline Variable & Coefficient & Std. Error & t-Statistic & Prob \\
\hline LNFDI & $2.40 \mathrm{E}-10$ & $7.85 \mathrm{E}-11$ & 3.051516 & 0.0057 \\
\hline LNHCD & 0.006648 & 0.002515 & 2.643389 & 0.0145 \\
\hline LNHCEXP & $-8.30 \mathrm{E}-11$ & $1.60 \mathrm{E}-11$ & -5.202376 & 0.0000 \\
\hline LNGEXP & $-1.38 \mathrm{E}-10$ & $5.76 \mathrm{E}-11$ & -2.403055 & 0.0247 \\
\hline LNINF & -0.005884 & 0.001654 & -3.557314 & 0.0017 \\
\hline LNNRA & 0.019561 & 0.004212 & 4.644046 & 0.0001 \\
\hline LNREX & -0.000457 & 0.000280 & -1.634333 & 0.1158 \\
\hline LNWY & 8.89E-14 & $3.54 \mathrm{E}-14$ & 2.510811 & 0.0195 \\
\hline TLB & 0.300292 & 0.072846 & 4.122316 & 0.0004 \\
\hline $\mathrm{C}$ & 0.480935 & 0.119444 & 4.026445 & 0.0005 \\
\hline
\end{tabular}

Source: Data used for regression analysis

Adjusted R-squared=0.87, D-W=2.22, F-statistic $=25.65$, Prob $($ F-statistic $)=0.000000, \mathrm{~N}=33$
The symbol *, ** and $* * *$ indicates the statistical significance at $1 \%, 5 \%$ and at $10 \%$ level respectively. 
Table 3. Diagnostic test

\begin{tabular}{lrll}
\hline $\begin{array}{l}\text { Breusch-Godfrey Serial Correlation LM Test: } \\
\text { Obs*R-squared }\end{array}$ & $\mathbf{2 . 2 9 8 1 6 3}$ & Prob. Chi-Square(2) & $\mathbf{0 . 3 1 6 9}$ \\
\hline $\begin{array}{l}\text { Heteroskedasticity Test: Breusch-Pagan-Godfrey } \\
\text { Obs*R-squared }\end{array}$ & Prob. Chi-Square(9) & 0.5771 \\
$\begin{array}{l}\text { Normality test } \\
\text { Jarque bera }\end{array}$ & & \\
\hline
\end{tabular}

Source: Data used for regression analysis

\subsection{The Empirical Results and Interpretation of the Regression}

From the results of regression (table 2) it was found that the adjusted R-squared is (0.87) which is significant to explain the good fitness of the model, the overall significance of the model at 1 percent is shown by F-test result with a prob $(0.000000)$ and the value of Durbin Watson DW (2.22) is significant to indicate that the sign of the absence of serial correlation. The unit root test also shows that all the variables were stationery after the first differences and that they follow the I (1) series.

The results identified that all variables are found to be significant at 5 percent level and had the correct sign as hypothesized these variables are the Foreign direct investment, Human capital development, Household consumption expenditure, Government expenditure, Inflation, Natural resources availability and foreign income. Except the real exchange rate the only variable that was found to be insignificant.

Specifically the foreign direct investment had positive coefficient elasticity of 2.40E-10 implying that an increase of the foreign direct investment by 1 percent would lead to an increase of trade balance by $2.40 \mathrm{E}-10$.

Human capital development had a positive coefficient sign and significant at 1 percent level with a an elasticity of 0.006648 implying that an increase of Human capital development by 1 percent would lead to an improvement of trade balance by 0.006648 percent, Household consumption expenditure had a negative significant sign implying that an increase of Household consumption expenditure by 1 percent reduces trade balance by $-8.30 \mathrm{E}-11$ percent.

Government expenditure had elasticity of $-1.38 \mathrm{E}-10$ implying an increase of government expenditure by 1 percent would lead to a deterioration of trade balance by $-1.38 \mathrm{E}-10$, a rise in inflation by 1 percent would lead to the deterioration of trade balance by -0.005884 percent, more discoveries of availability of mineral resources by 1 percent would lead to an improvement of trade balance by 0.019561 , a rise in foreign income by 1 percent leads to an improvement of trade balance by $8.89 \mathrm{E}-14$ and finally the trade liberalization impacts positively on trade balance as expected though in reality this is not the case as we have seen the trade deficit become more widened until recently.

The results of this study collaborates with [16] in only three variables namely Government expenditure, household consumption and trade liberization which were the main determinant of trade balance in Tanzania. However in his study he also found that foreign direct investment and foreign income to be insignificant variable which makes the contradiction to this study, but it seems that these contradictions results can be explained by the inclusion of more variables that has been used in this study.

Real exchange rate was found to be insignificant with a correct sign as hypothesized therefore was not included among the major determinants of trade balance in Tanzania but this results collaborates with [16]in his study who also got the negative insignificant real exchange rate and concluded that devaluation is not the solution for promoting export in Tanzania however the results contradict with [4]in his study of the determinant of trade balance in Kenya who discovered that the exchange rate was a significant variable. The general prob (F-statistics) found to be significant at 1 percent level which imply that the independent variables jointly can influence dependent variables and the F-statistics value which is also significant with the highest value of 25.65 implying that the model was well specified.

Finally the diagnostic test was conducted to check the viability of the model and the results showed that the model is not serially correlated, homoscedastic and residual are well normally distributed as indicated by their probabilities way higher than 5 percent level not to reject the null hypothesis(see table 3).

The stability test was conducted and the results indicated that the model is stable in both CUSUM AND CUSUM SQUARE at 5 percent level (see figure $2 \mathrm{a} \& 2 \mathrm{~b}$ ) below in the appendix 1 .

\section{Conclusion and Policy Advices}

The study is highly motivated by the trade deficit that has been existed for so many years in Tanzania. First the preliminary unit root test (ADF and phillip perron test) were conducted and the results showed that all the variables were not stationery at levels but were all stationery after the first difference implying that they follow the I (1) series. The next step was to use the Ordinary least square (OLS) technique to estimate the relationship between trade balance and its determinants. All this were done using E-views 7.1software. The general regression results showed that the major determinants of trade balance for Tanzania are foreign direct investment, Human capital development, Household consumption expenditure, Government expenditure, 
Inflation, Natural resources availability and foreign income. Therefore policy formulation should base on them in order to improve the trade balance in Tanzania.

Some policy advice like continuation of a more conducive investment climate in Tanzania is important to encourage more multinational companies to come and invest in the country especially those with that target to export from the country. The reduction of both government and household consumption will be the best move to make in the economy. More facilities and opportunities for the people to get more education are necessary to increase the number of educated people in the country that can increase the production level hence improve the trade balance.

The need for more exploration of the new discoveries of natural resources like minerals and natural gas is also important to ensure it availability that can have an impact on the quantity to be supplied which can boost the level of export for example the very recent massive discoveries of the natural gas in Tanzania could have the great positive impact in the near future on the trade balance and the economy as a whole as it will attract more investments both domestic and foreign ones that will increase the capacity to export hence realization of the positive trends on the trade balance. Like the previous studies e.g [16] devaluation of shillings is not the appropriate step to follow as indicated on the results,other good measure of currency stabilization are necessary to improve trade balance. Finally the economy need to be more gradually liberized but always with cautious means in order to improve the trade balance as it was found in this study that trade liberization was among the main factor in Tanzania which have a positive impact although in reality it has never been the case as it has also been observed that trade balance has been more deteriorated where we see the increase of imports from U.S.A, India, China, South Africa, U.K et.c than the export to those countries.

\section{Further Research}

The scope of this study covers about 33 years as sample period of study for Tanzania and used a simple ordinary least square (OLS) technique as an estimation method. In this case in order to ensure maximum exploration and exhaustion of the variables that can give the robust results further studies on the determinants of balance of trade is needed especially using other econometric measuring techniques with broader sample period of study and more variables to be included, for example this study has only used USA GDP as a proxy to represent the world income due to the difficulties to get data on other countries therefore the results in this study should be cautiously be interpreted.

\section{Appendix 1}

\section{The Stability Test}

(Figure 2a\&2b) Plot of Cumulative Sum and cumulative sum of Squares of Recursive Residuals
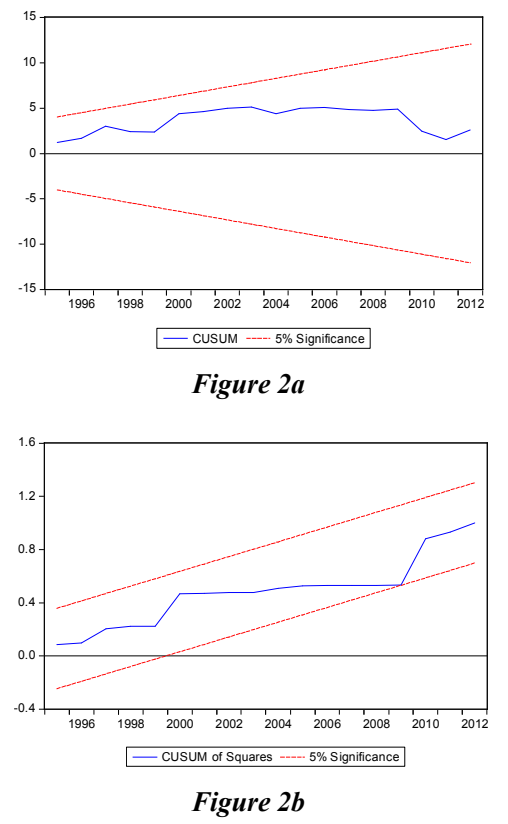

\section{References}

[1] Bahmani-Oskooee, M. (2001) Nominal and real effective exchange rates of Middle Eastern countries and their trade performance. Applied Economics, 33, 103-111

[2] Bahmani-Oskooee M. and Brooks T.J., (1999) Bilateral J-curve between US and her trading partners, Weltwirtschaftliches Archive, 135(1), 156-165.

[3] Dickey, F. (1979). Distribution of the Estimators for Autoregressive time series with Unit Roots. Journal of American Statistical Associations.

[4] Edward nienga (2010) the determinants of trade balance in Kenya; an empirical analysis; 1970-2010.

[5] Fuller.(1979).Dickey,D.A.andW.A.Fuller(1979),"Distributio $\mathrm{n}$ of the Estimators for Autoregressive Time Series with a Unit Root. Journal of the American Statistical Association, 74, p. $427-431$.

[6] Festus O. Egwaikhide (2002) Effects of Budget Deficit on Trade Balance in Nigeria: A Simulation Exercise; African Development Review volume 11, Issue 2, pages 265-289.

[7] Har wai-mum, Ng yuen-ling, Tan Geoi-Mei (2008) Real exchange rate and trade balance Relationship: An Empirical study on Malaysia.

[8] Imam Sugema (2005) The Determinants of Trade Balance and Adjustment to the Crisis in Indonesia. Paper No. 0508.

[9] Korap, Levant (2011): An empirical model for the Turkish trade balance: new evidence from ARDL bounds testing analyses. Published in:Istanbul University Department of Economics Econometrics and Statistics, Vol. 14, (2011): pp. 38-61.

[10] Lal, Anil K. and Lowinger, Thomas C. (2001) "J -Curve: Evidence from East Asia," manuscript presented at the 40th Annual Meeting of the Western Regional Science Association February 2001 in Palm Springs, CA. 
[11] M.zakir saadullar k., M.ismail h. (2012) Determinants of Trade Balance of Bangladesh: A Dynamic Panel Data Analysis. Bangladesh Development Studies Vol. XXXV, June 2012, No. 2.

[12] Magee, S.P. (1973), 'Currency Contracts, Pass-through, and Devaluation', Brookings, Papers on Economic Activity; 1, pp. 303-23.

[13] Peter W. and Sarah T. (2006) the trade balance effects of U.S. foreign direct investment in Mexico.

[14] Phillips-Perron. (1988). Testing for a Unit Root in Time Series Regression". Biometrika, 75, 335-346.
[15] Rose and Yellen (1989, p. 58) an empirical analysis of Korea's trade imbalances with the US and Japan.

[16] Sayuni mbayani (2006) Determinants of trade balance in Tanzania, A research paper towards the fulfillment of masters of Arts degree in economic policy management (PPT),Makerere University.

[17] Waliullah, Mehmood k.k, Rehmatullah.K and wekeel.k. (2010).The Determinants of Pakistan's Trade Balance: An ARDL Co integration Approach. The Lahore Journal of Economics 15: 1 (summer 2010): pp. 1-26. 